\title{
The effect of maternal iron deficiency on zinc and copper levels and on genes of zinc and copper metabolism during pregnancy in the rat
}

\author{
Sarah C. Cottin ${ }^{1}$, Guenievre Roussel ${ }^{2}$, Lorraine Gambling ${ }^{3}$, Helen E. Hayes ${ }^{3}$, Valerie J. Currie ${ }^{3}$ and \\ Harry J. McArdle ${ }^{3 *}$ \\ ${ }^{1}$ Division of Food and Drink, School of Science Engineering and Technology, Abertay University, Dundee DD1 1HG, UK \\ ${ }^{2}$ Laboratoire de Neurosciences Cognitives, Aix-Marseille Université, 13331 Marseille, France \\ ${ }^{3}$ Rowett Institute of Nutrition and Health, University of Aberdeen, Foresterbill House, Ashgrove Road West, Aberdeen \\ AB25 2ZD, UK \\ (Submitted 4 May 2018 - Final revision received 9 September 2018 - Accepted 17 September 2018 - First published online 28 November 2018)
}

\begin{abstract}
Fe deficiency is relatively common in pregnancy and has both short- and long-term consequences. However, little is known about the effect on the metabolism of other micronutrients. A total of fifty-four female rats were fed control $(50 \mathrm{mg} \mathrm{Fe} / \mathrm{kg})$ or Fe-deficient diets (7.5 mg/kg) before and during pregnancy. Maternal liver, placenta and fetal liver were collected at day 21 of pregnancy for $\mathrm{Cu}$ and $\mathrm{Zn}$ analysis and to measure expression of the major genes of $\mathrm{Cu}$ and $\mathrm{Zn}$ metabolism. Cu levels increased in the maternal liver $(P=0 \cdot 002)$ and placenta $(P=0 \cdot 018)$ of Fe-deficient rats. $\mathrm{Zn}$ increased $(P<0.0001)$ and $\mathrm{Cu}$ decreased $(P=0.006)$ in the fetal liver. Hepatic expression of the $\mathrm{Cu} c h a p e r o n e s$ antioxidant $1 \mathrm{Cu}$ chaperone $(P=0.042)$ and cytochrome $c$ oxidase $\mathrm{Cu}$ chaperone $(C O X 17, P=0 \cdot 020)$ decreased in the Fe-deficient dams, while the expression of the genes of $\mathrm{Zn}$ metabolism was unaltered. In the placenta, Fe deficiency reduced the expression of the chaperone for superoxide dismutase 1 , Cu chaperone for superoxide dismutase $(P=0 \cdot 030)$, ceruloplasmin $(P=0 \cdot 042)$ and Zn transport genes, ZRT/IRT-like protein $4(Z I P 4, P=0 \cdot 047)$ and $Z n$ transporter $1(Z n T 1, P=0 \cdot 012)$. In fetal liver, Fe deficiency increased COX17 $(P=0 \cdot 020), Z$ ZRT/IRT-like protein $14(P=0.036)$ and $Z n T 1(P=0.0003)$ and decreased $Z I P 4(P=0.004)$. The results demonstrate that Fe deficiency during pregnancy has opposite effects on $\mathrm{Cu}$ and $\mathrm{Zn}$ levels in the fetal liver. This may, in turn, alter metabolism of these nutrients, with consequences for development in the fetus and the neonate.
\end{abstract}

Key words: Placenta: Liver: Iron status: Copper: Pregnancy

Fe deficiency is the most common nutrient deficiency worldwide and is particularly prevalent in children, women of child bearing age and pregnant women. Even in the UK, it is estimated that $23 \%$ of women aged 19-64 years and nearly half of teenage girls do not reach their lower reference nutrient intake for $\mathrm{Fe}^{(1)}$. During development, the fetus relies entirely on maternal supply for $\mathrm{Fe}, \mathrm{Zn}$ and $\mathrm{Cu}$, which are critical for development and health. Crosstalks between these three trace elements have been established decades ago ${ }^{(2-4)}$, but the effect of Fe deficiency on the metabolism of $\mathrm{Cu}$ and $\mathrm{Zn}$ is still not fully understood, particularly during pregnancy. The ability to carry out work establishing these links is, of course, limited, but micronutrient metabolism is well-conserved in mammals, and the rat has been shown to be a very good model for pregnancy and nutrition in humans ${ }^{(3)}$.

Generally, Fe deficiency in mammals results in increased $\mathrm{Cu}$ levels in the blood, gut and liver ${ }^{(5-7)}$. Circulating ceruloplasmin (CP), produced by the liver, and its gut homologue hephaestin are $\mathrm{Cu}$-dependent ferroxidases and appear as an evident link between $\mathrm{Fe}$ and $\mathrm{Cu}$ metabolism. Accordingly, Fe deficiency in rats induces an increase in serum $\mathrm{Cu}$ associated with an increase in $C P$ levels ${ }^{(5)}$. Interestingly, Fe-deficient rats have higher liver $\mathrm{Cu}$ levels that correlate with $\mathrm{CP}$ expression and its ferroxidase activity, while hepatic $C P$ mRNA remains unchanged, suggesting that $\mathrm{Cu}$ loading is associated with an increased metallation of the protein ${ }^{(8)}$. Fe deficiency also increases the expression of the Menkes Cu ATPase (ATP7a) in the duodenum ${ }^{(6,9)}$, suggesting an increased export of $\mathrm{Cu}$ from the enterocyte to the circulation, while Wilson $\mathrm{Cu}$ ATPase $(A T P 7 b)$ expression in the liver is unaltered ${ }^{(6)}$. In addition, $\mathrm{Cu}$ and Fe may compete for divalent metal transporter 1 (DMT1) for their uptake in the gut. Although Cu influx through DMT1 in the enterocyte is minor compared with $\mathrm{Cu}$ transporter 1 (CTR1) in replete conditions, it is of particular importance during Fe deficiency due to its up-regulation and the lack of $\mathrm{Fe}$ in the lumen, which favours $\mathrm{Cu}$ uptake ${ }^{(10)}$.

Abbreviations: ATOX1, antioxidant 1 copper chaperone; CCS, copper chaperone for superoxide dismutase; COX17, cytochrome c oxidase copper chaperone; $\mathrm{CP}$, ceruloplasmin; ZIP, ZRT/IRT-like protein; ZnT, zinc transporter.

* Corresponding author: Professor H. J. McArdle, email h.mcardle@abdn.ac.uk 
The effect of Fe deficiency on Zn status is believed to be less important than on $\mathrm{Cu}$ status. Fe deficiency appears to reduce $\mathrm{Zn}$ requirements in rats, increasing Zn levels in several organs such as liver, spleen, brain or kidney ${ }^{(11,12)}$ while decreasing apparent $\mathrm{Zn}$ absorption ${ }^{(13)}$ and plasma $\mathrm{Zn}^{(14)}$. Noteworthy, marginal $\mathrm{Fe}$ deficiency $(9$ and $13 \mathrm{mg} \mathrm{Fe} / \mathrm{kg}$ diet) did not affect $\mathrm{Zn}$ status in rat, while it was sufficient to induce $\mathrm{Cu}$ accumulation in the liver ${ }^{(15)}$. Because $\mathrm{Fe}$ and $\mathrm{Zn}$ have similar mechanisms of absorption and transport in the gut, they were originally thought to compete with each other, notably through DMT1. Accordingly, Fe treatment reduces the transport of $\mathrm{Zn}$ in Caco-2 cells although to a lesser extent than other divalent cations ${ }^{(16)}$. However, DMT1's affinity for $\mathrm{Zn}$ is much lower than that for Fe, and its contribution to $\mathrm{Zn}$ transport and uptake is probably minimal $^{(17)}$

Two families of $Z n$ transporters ( $\mathrm{n} T$ ) have been identified, ZRT/IRT-like protein (ZIP) and ZnT, generally involved in influx and efflux of the cells, respectively. ZIP stands for Znregulated transporter, Fe-regulated transporter-like protein, and is composed of 14 members in mammals. They are characterised by their ability to transport $\mathrm{Zn}$, but several of them have also been reported to mediate the uptake of Fe as well as $\mathrm{Mn}^{(18)}$. In rats, Fe overload increases the expression of several ZIP in the liver, namely, ZIP5 (up), ZIPG, ZIP7 and ZIP10 (down), while ZIP14, the most abundant ZIP in the liver, is upregulated by Fe deficiency ${ }^{(19)}$. On the other hand, the $Z n T$ family comprises 10 members so far and contribute to $\mathrm{Zn}$ homoeostasis by exporting $\mathrm{Zn}$ out of the cell or sequestrating $\mathrm{Zn}$ into cellular compartments when $\mathrm{Zn}$ levels are low. While there is evidence for direct action of Fe on ZIP, which may lead to alterations in $\mathrm{Zn}$ metabolism, interactions between $\mathrm{Fe}$ and ZnT have not been identified.

Metabolic crossroads between $\mathrm{Fe}, \mathrm{Cu}$ and $\mathrm{Zn}$ during pregnancy are less known. Maternal Fe deficiency in rat increases $\mathrm{Cu}$ levels in the maternal liver, maternal serum as well as the placenta $^{(20,21)}$ along with an increase in serum $\mathrm{Cu}$ and $\mathrm{CP}^{(22)}$. In contrast, we showed that Fe deficiency decreased Cu levels in the fetal liver, without affecting the fetal expression of the main genes involved in $\mathrm{Cu}$ metabolism ${ }^{(23,24)}$. In humans, Fe supplementation has been shown to decrease plasma $\mathrm{Zn}$ levels during pregnancy and $\mathrm{Zn}$ absorption during lactation in humans ${ }^{(25-27)}$. Whether Fe deficiency, as opposed to overload, affects $\mathrm{Zn}$ metabolism in the mother and fetus remains essentially unknown. In this study, we investigated the effect of maternal Fe deficiency on $\mathrm{Zn}$ status in pregnant rats and the offspring as well as the implication of major genes of $\mathrm{Zn}$ metabolism. We also examined the mechanisms through which Fe deficiency differentially affects $\mathrm{Cu}$ metabolism in the mother and fetus and tested the implication of most genes of $\mathrm{Cu}$ metabolism in the liver of the mother and fetus as well as in the placenta.

\section{Methods}

\section{Animal procedures}

Experiments were performed using female Rowett hooded rats from three different studies of identical design. The protocol and animal procedures have recently been described in detail $^{(28)}$ and were approved by the Rowett Institute Ethics Committees and conducted in accordance with the UK Animals (Scientific Procedures) Act 1986. Briefly, 54 weanling females were fed a control diet (AIN93, containing $860 \mathrm{mg} / \mathrm{kg} \mathrm{Zn} \mathrm{and}$ $170 \mathrm{mg} / \mathrm{kg} \mathrm{Cu}$ ) for two weeks and were then randomised into two groups. In all, 30 remained on the control diet $(\mathrm{Fe}=50 \mathrm{mg} / \mathrm{kg})$ for four weeks until mating and 24 switched to an Fe-deficient $(\mathrm{Fe}=7.5 \mathrm{mg} / \mathrm{kg})$ diet for the same duration. They were mated with males of the same strain and remained on the same diet until they were killed at day 21 of gestation. Dams were killed by stunning and cervical dislocation and the fetuses by decapitation. Animals were housed under 12-h light12 -h dark cycle with a constant temperature $\left(22^{\circ} \mathrm{C}\right)$. No adverse effects were recorded as a result of this dietary intervention.

Livers from the dams and fetuses, as well as the placentas, were collected and immediately frozen in liquid $\mathrm{N}_{2}$. They were kept in metal-free vials and stored at $-80^{\circ} \mathrm{C}$ until analysis. Whenever possible, placentas and fetal livers from the three male median weights in each litter were pooled together and ground in liquid $\mathrm{N}_{2}$. Ground tissues from maternal liver, pooled placentas and pooled fetal livers were used for $\mathrm{Fe}, \mathrm{Cu}$ and $\mathrm{Zn}$ content (control $n$ 24, Fe deficient $n$ 30) and gene analysis (control $n 21$, Fe deficient $n 24$ ). It should be noted that control and Fe-deficient samples from each of the three animal studies were analysed together, and results from each experiment were then pooled together for data analysis.

\section{Assessment of copper and zinc status}

Total $\mathrm{Cu}$ and $\mathrm{Zn}$ were measured in maternal liver, placenta and fetal liver by inductively coupled plasma (ICP)-MS as described previously ${ }^{(28)}$. Samples were digested in $2 \% \mathrm{HNO}_{3}, 0.5 \% \mathrm{HCl}$ and metal concentrations measured using an Agilent $7700 \mathrm{X}$ spectrophotometer (Agilent Technologies) equipped with a MicroMist nebuliser, Ni sampler and skimmer cones. Intra-assay CV\% were $10.8 \%(\mathrm{Fe}), 11 \cdot 1 \%(\mathrm{Cu})$ and $5.2 \%(\mathrm{Zn})$.

\section{RNA extraction and real-time $R T$-quantitative $P C R$}

In all, 20-30 mg of frozen placenta, maternal and fetal liver ground tissue were homogenised after grinding, using a T25 Ultra-Turrax (IKA (England) Ltd). RNA was isolated with the RNeasy Mini Kit (Qiagen), and 200 ng was reverse transcribed on a PTC-100 Thermal Cycler (Bio-Rad Laboratories) using the Applied Biosystems TaqMan RT reagent kit (Life Technologies). Complementary DNA fragments were amplified by real-time quantitative PCR (7700 Sequence Detection System; Life Technologies) using the primers (TaqMan; ThermoFisher Scientific) described in Table 1. The most relevant genes of $\mathrm{Cu}^{(24)}$ and $\mathrm{Zn}$ metabolism were selected. Specifically, ZIP-1 is ubiquitously expressed and was shown to bind Fe with high affinity ${ }^{(29)}$. $Z I P-4$ is crucial during development and for the absorption of maternal $\mathrm{Zn}^{(30)}$. ZIP8 and ZIP14 are closely related and have been shown to mediate $\mathrm{Fe}$ transport in addition to $\mathrm{Zn}^{(31,32)}$. $Z n T 1$ (ubiquitous), $Z n T 4$ and $Z n T 5$ are sensitive to maternal $Z n$ status and may play an important role in fetal $Z n$ supply from the maternal diet ${ }^{(33,34)}$. The gene expression was normalised to 18s rRNA (HS99999901_s1) in all samples. This was chosen 
Table 1. List of genes analysed by PCR using TaqMan ${ }^{\circledR}$ Gene Expression Assays (ThermoFisher Scientific)

\begin{tabular}{|c|c|c|}
\hline Gene & Protein & Assay ID \\
\hline ATOX1 & Antioxidant $1 \mathrm{Cu}$ chaperone & Rn00584459_m1 \\
\hline$C O \times 17$ & $\begin{array}{l}\text { Cytochrome } c \text { oxidase } \\
\text { Cu chaperone }\end{array}$ & Rn00585530_m1 \\
\hline CCS & $\begin{array}{l}\text { Cu chaperone for } \\
\text { superoxide dismutase }\end{array}$ & Rn00584772_m1 \\
\hline$C P$ & Ceruloplasmin & Rn00561049_m1 \\
\hline ATP7A & $\begin{array}{l}\text { ATPase Cu transporting } \\
\text { alpha (Menkes) }\end{array}$ & Rn00583815_m1 \\
\hline ATP7B & $\begin{array}{l}\text { ATPase Cu transporting } \\
\text { beta (Wilson) }\end{array}$ & Rn00560862_m1 \\
\hline SLC31A1/CTR1 & Cu transporter 1 & Rn00683634_m1 \\
\hline SLC39A1/ZIP1 & ZRT/IRT-like protein 1 & Rn01458936_g1 \\
\hline SLC39A4/ZIP4 & ZRT/IRT-like protein 4 & Rn01505595_g1 \\
\hline SLC39A8/ZIP8 & ZRT/IRT-like protein 8 & Rn01748352_m1 \\
\hline SLC39A14/ZIP14 & ZRT/IRT-like protein 14 & Rn01468336_m1 \\
\hline SLC30A1/ZnT1 & Zn Transporter 1 & Rn00575737_m1 \\
\hline SLC30A4/ZnT4 & Zn Transporter 4 & Rn00597094_m1 \\
\hline SLC30A5/ZnT5 & Zn Transporter 5 & $\mathrm{Rn} 01493867 \mathrm{~m} 1$ \\
\hline
\end{tabular}

although the levels of expression were higher than the test genes because it was the only gene that was consistently unaffected by the nutritional treatments ( $G$ Roussel and $H J$ McArdle, unpublished results).

The experiment was performed and data interpreted according to the Minimum Information for Publication of Quantitative Real-Time PCR Experiments guidelines ${ }^{(35)}$ : 18s RNA expression did not significantly vary between the Fedeficient and control groups in all tissues (Mann-Whitney test, data not shown). Linear amplification was observed for $18 \mathrm{~s}$ and all genes of interest across their range of expression.

\section{Statistical analysis}

$\mathrm{Fe}, \mathrm{Cu}$ and $\mathrm{Zn}$ content are expressed in $\mu \mathrm{g} / \mathrm{g}$ dry tissue. The material used in this article were obtained from three separate experiments. To minimise variations between the three animal studies, as well as between each PCR run, the expression of $\mathrm{Cu}$ and $\mathrm{Zn}$ genes was expressed as percentage of the average gene expression of the control group for each of the three experiments. The normality of the distribution and equality of variances were analysed with GraphPad Prism (version 5.04). Data were analysed with IBM SPSS statistics 21.0 software using unpaired $t$ tests when data were normally distributed and otherwise using non-parametric tests (Mann-Whitney $U$ ).

\section{Results}

\section{Copper and zinc levels}

The effect of maternal Fe deficiency on growth, placental:fetal ratio, placenta and liver weights, haematocrit and Fe levels in this study has been recently reported ${ }^{(28)}$. Specifically, Fe levels were decreased by $152.6 \mu \mathrm{g} / \mathrm{g}$ (approximately $-30 \%$ ), $604.0 \mu \mathrm{g} / \mathrm{g}$ (approximately $-60 \%$ ) and 369.4 $\mu \mathrm{g} / \mathrm{g}$ dry tissue (approximately $-75 \%$ ), in the placenta, fetal and maternal liver, respectively $^{(28)}$. Maternal liver and placenta weight were not
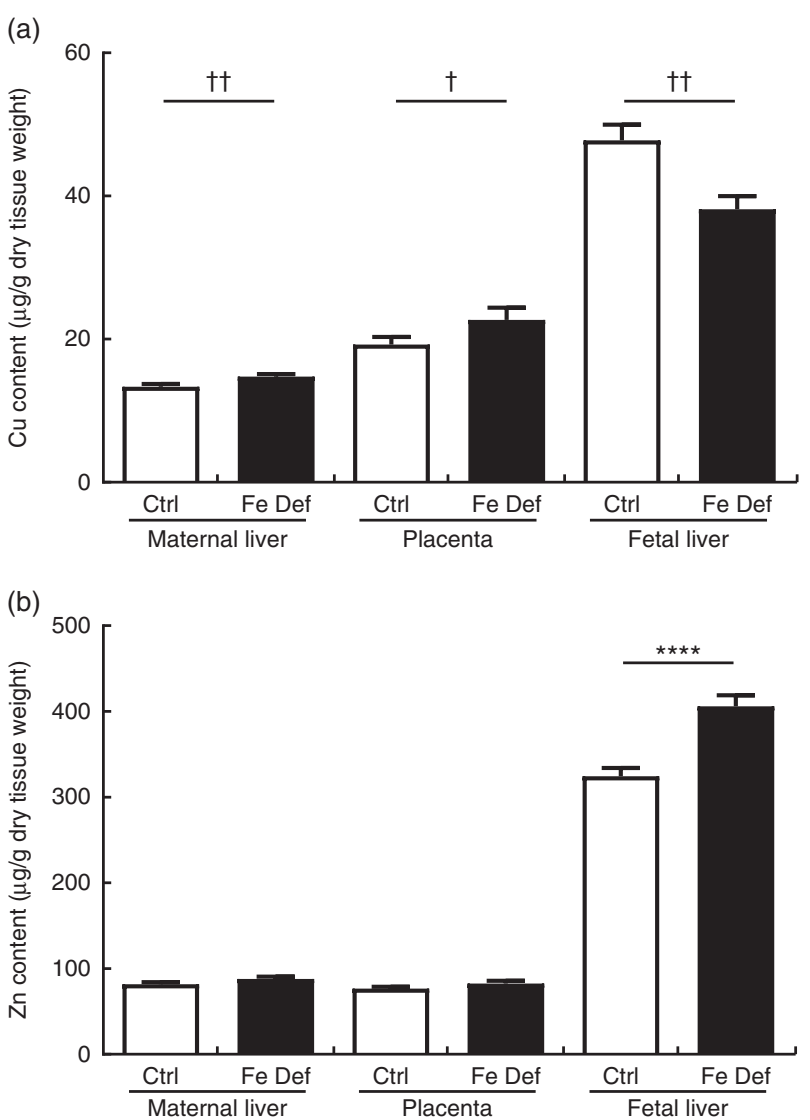

Fig. 1. Effect of maternal iron deficiency on copper (a) and zinc (b) levels in maternal liver, placenta and fetal liver $21 \mathrm{~d}$ after mating ( $n 54)$. Values are mean percentage of control, with their standard errors represented by vertical bars. Results are significantly different between the control (Ctrl, $n$ 24) and iron-deficient (Fe Def, $n$ 30) groups: ${ }^{\star * \star *} P<0.0001$ (independent $t$ test); $\dagger P<0.05$, †† $P<0.01$ (Mann-Whitney test).

affected by Fe deficiency, while fetal weight and fetal liver weight were significantly decreased by approximately $13 \%$ and $25 \%$, respectively ${ }^{(28)}$. Maternal Fe deficiency increased $\mathrm{Cu}$ levels by $1.44 \mu \mathrm{g} / \mathrm{g}$ dry tissue (95\% CI $0.34,2.54 ; P=0.002)$ and $3.45 \mu \mathrm{g} / \mathrm{g}(95 \% \mathrm{CI}-0.42,7 \cdot 32 ; P=0.018)$ in maternal liver and placenta, respectively. In contrast, Fe deficiency decreased $\mathrm{Cu}$ levels in the fetal liver by $9 \cdot 64 \mu \mathrm{g} / \mathrm{g}$ (95\% CI $-15 \cdot 85,-3 \cdot 42$; $P=0.006$ ) (Fig. 1(a), Mann-Whitney), while $\mathrm{Zn}$ levels were increased by $81.6 \mu \mathrm{g} / \mathrm{g}$ (95\% CI 50.0, 113.1; P<0.0001). Zn levels in maternal liver and placenta were not significantly altered by maternal Fe deficiency (Fig. 1(b), $t$ test). Changes in absolute levels of $\mathrm{Fe}, \mathrm{Zn}$ and $\mathrm{Cu}$ followed a similar pattern (Table 2) apart from the absolute $\mathrm{Zn}$ levels that were reduced by $4.08 \mu \mathrm{g}(95 \% \mathrm{CI}-1.64,-6.52 ; P=0.003)$ in the fetal liver.

\section{Zinc and copper gene expression}

Maternal Fe deficiency decreased the hepatic expression of the $\mathrm{Cu}$ chaperones antioxidant $1 \mathrm{Cu}$ chaperone (ATOX1) by $-10 \cdot 5 \%(95 \% \mathrm{CI}-20 \cdot 7,-0 \cdot 4 ; P=0.042)$ and cytochrome $c$ oxidase $\mathrm{Cu}$ chaperone (COX17) by $-13 \cdot 8 \%$ (95\% CI $-25 \cdot 3,-2 \cdot 3$; $P=0.020)$ in the dams. In contrast, the hepatic expression of COX 17 was increased by $15 \cdot 0 \%(95 \%$ CI $2 \cdot 5,27 \cdot 5 ; P=0 \cdot 020)$ in 
Table 2. Organ weight, water content and absolute iron, copper and zinc content in the maternal liver, placenta and fetal liver of control and iron-deficient rats at day 21 of gestation (Mean values with their standard errors)

\begin{tabular}{|c|c|c|c|c|}
\hline & \multicolumn{2}{|c|}{ Control } & \multicolumn{2}{|c|}{ Fe deficient } \\
\hline & Mean & SEM & Mean & SEM \\
\hline \multicolumn{5}{|l|}{ Maternal liver } \\
\hline Organ weight (g)‡ & 10.94 & 0.39 & 11.60 & 0.35 \\
\hline Water content (\%)§ & 70.04 & 0.26 & $71 \cdot 22^{\star \star}$ & 0.24 \\
\hline Absolute Fe content $(\mathrm{mg}) \ddagger$ & 1.96 & 0.29 & $0.70 \dagger \dagger$ & $0 \cdot 12$ \\
\hline Absolute $\mathrm{Cu}$ content $(\mu \mathrm{g}) \ddagger$ & 44.77 & 1.20 & $51 \cdot 10^{*}$ & 1.48 \\
\hline Absolute $\mathrm{Zn}$ content $(\mu \mathrm{g}) \ddagger$ & 305.9 & $8 \cdot 2$ & $326 \cdot 8$ & 8.5 \\
\hline \multicolumn{5}{|l|}{ Placenta } \\
\hline Organ weight (g)\| & 0.512 & 0.017 & 0.551 & 0.009 \\
\hline Water content $(\%) \S$ & 87.83 & 0.24 & $88 \cdot 10$ & 0.27 \\
\hline Absolute Fe content (mg)\| & 39.07 & 1.88 & $28 \cdot 47^{\star \star \star}$ & 1.66 \\
\hline Absolute Cu content $(\mu \mathrm{g}) \|$ & $1 \cdot 17$ & $0 \cdot 10$ & 1.52 & 0.09 \\
\hline Absolute Zn content $(\mu \mathrm{g}) \|$ & 5.52 & 0.20 & 5.60 & $0 \cdot 19$ \\
\hline \multicolumn{5}{|l|}{ Fetal liver } \\
\hline Organ weight $(\mathrm{g}) \ddagger$ & 0.313 & 0.009 & $0.234^{\star \star *}$ & 0.009 \\
\hline Water content $(\%) \S$ & $78 \cdot 23$ & 0.21 & $79 \cdot 26^{\star}$ & 0.18 \\
\hline Absolute Fe content (mg)‡ & $80 \cdot 37$ & $2 \cdot 38$ & $20 \cdot 08+\dagger \dagger$ & $1 \cdot 14$ \\
\hline Absolute $\mathrm{Cu}$ content $(\mu \mathrm{g}) \ddagger$ & 3.62 & 0.27 & $1.90^{\star \star \star}$ & 0.15 \\
\hline Absolute Zn content $(\mu \mathrm{g}) \ddagger$ & 23.37 & 0.87 & $19 \cdot 27^{\star \star}$ & 0.85 \\
\hline
\end{tabular}

Mean values were significantly different compared with control: ${ }^{*} P<0.05$, ${ }^{\star *} P<0.01,{ }^{* \star *} P<0.001$ (independent $t$ test).

Mean values were significantly different compared with control: $+\dagger P<0.01$, $† \dagger \dagger P<0.001$ (Mann-Whitney $U$ test).

$\ddagger n 16$ (eight control, eight Fe deficient).

$\S n 54$ (twenty-four control, thirty Fe deficient).

I $n 38$.

the fetus. In the placenta, Fe deficiency led to a decrease in $\mathrm{Cu}$ chaperone for superoxide dismutase (CCS), the chaperone that delivers $\mathrm{Cu}$ to superoxide dismutase (SOD) 1 , by $-9.5 \%$ (95\% CI $-18 \cdot 0,-1 \cdot 0 ; P=0 \cdot 030)$ and $C P$ by $-15 \cdot 0 \%(95 \%$ CI $-29 \cdot 4,-0 \cdot 5$; $P=0.042$ ) expression (Fig. 2).

The maternal hepatic expression of the genes related to $\mathrm{Zn}$ metabolism was not affected by Fe deficiency. In the placenta, ZIP4 was reduced by $-23.7 \%$ (95\% CI $-47 \cdot 0,-0 \cdot 4 ; P=0.047)$ and $Z n T 1$ by $-12 \cdot 3 \%$ (95\% CI $21 \cdot 8,-2 \cdot 8 ; P=0 \cdot 012)$ in the Fedeficient group compared with control (Fig. 3). In fetal liver, Fe deficiency also decreased ZIP4 by $-17 \cdot 0 \%$ (95\% CI -28.1, -5.8; $P=0.004)$, while ZIP14 and ZnT1 were increased by $10.0 \%$ (95\% CI $0.7,19.3 ; P=0.036$ ) and by $18.7 \%$ (95\% CI $9.0,28.4$; $P=0 \cdot 0003$ ), respectively (Fig. 3).

The effect of maternal Fe deficiency on $\mathrm{Cu}$ and $\mathrm{Zn}$ metabolism observed in the current study is summarised in Table 3.

\section{Discussion}

In this article, we examined the interactions between $\mathrm{Fe}, \mathrm{Cu}$ and Zn during pregnancy in the rat. The study has some limitations in that the data can only be extrapolated to humans to a limited extent. However, given how well-conserved micronutrient metabolism is between species, it is likely that the same results would be observed in humans with Fe deficiency. We restricted our measurements to liver and placenta, as these are the major organs involved in micronutrient metabolism ${ }^{(3)}$. Fe deficiency altered $\mathrm{Cu}$ but not $\mathrm{Zn}$ concentrations in the maternal liver and placenta, confirming that the metabolism of $\mathrm{Cu}$ is more sensitive to $\mathrm{Fe}$ deficiency than that of $\mathrm{Zn}^{(15)}$. However, maternal $\mathrm{Fe}$ deficiency had an important impact on both $\mathrm{Cu}$ and $\mathrm{Zn}$ levels in the fetal liver, which were reduced by approximately $15 \%$ and augmented by approximately $25 \%$, respectively.

\section{Effect of maternal iron deficiency on copper metabolism}

Maternal Fe deficiency leads to the hepatic accumulation of $\mathrm{Cu}$ in the dams, while Cu levels are decreased in the fetal liver, as described previously by our group, as well as others ${ }^{(20,21,23)}$. Interestingly, $\mathrm{Fe}$ deficiency decreased the expression of the chaperones ATOX1 and COX17 in the maternal liver, contrasting with our previous findings, where no change in ATOX1 mRNA levels was observed ${ }^{(23)}$. It is important to note that in our previous experiment, COX17 was not measured and ATOX1 was only measured in six samples. Further, the previous study used Northern blotting to detect expression levels which is less sensitive than using RT-PCR. The present study included 45 samples, which allows us to detect smaller changes with greater sensitivity.

$A T O X 1$ does not seem to be involved in $\mathrm{Cu}$ uptake but is a $\mathrm{Cu}$ chaperone that interacts with $A T P 7 A$ and $A T P 7 B$ and delivers $\mathrm{Cu}$ to these pumps and hence to trans-Golgi network ${ }^{(36)}$ or possibly the efflux pathway of the placenta ${ }^{(37)}$. Moreover, ATOX1 appears essential to peri-natal $\mathrm{Cu}$ homoeostasis ${ }^{(38)}$ for synthesis of $\mathrm{CP}$ or export from the cell into the portal circulation ( $A T P 7 A$ in gut) or into the bile for excretion $(A T P 7 B)$. Understandably, the inhibition of $A T O X 1$ expression reduces the trafficking of ATPases $^{(39)}$, thus reducing $\mathrm{Cu}$ export and causing its accumulation in the cell ${ }^{(40)}$. Therefore, the small but significant reduction in ATOX1 expression in the Fe-deficient liver could be responsible - at least partially - for the increase in Cu levels.

In addition, the hepatic expression of $\operatorname{COX} 17$, a chaperone delivering $\mathrm{Cu}$ to the cytochrome oxidase complex in the respiratory chain, was also decreased. The impairment of mitochondrial function and the reduction in cytochrome $c$ activity (which requires both $\mathrm{Fe}$ and $\mathrm{Cu}$ to function) is wellestablished in Fe-deficient tissues, including in the liver ${ }^{(41,42)}$, 

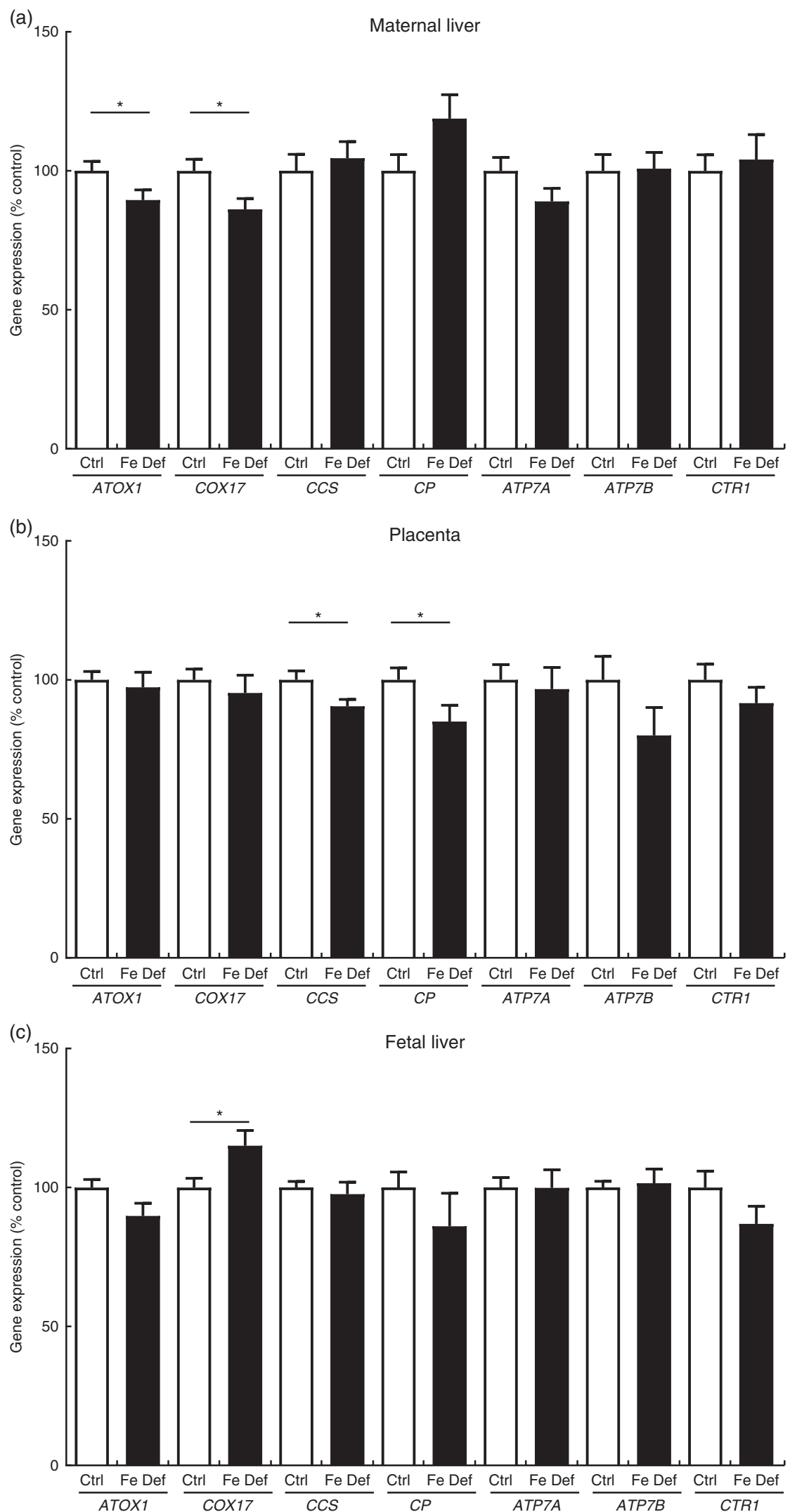

Fig. 2. Effect of maternal iron deficiency on the expression of genes related to copper metabolism ( $n 45) 21 \mathrm{~d}$ after mating: (a) maternal liver; (b) placenta; (c) fetal liver. Values are mean percentage of control, with their standard errors represented by vertical bars. ${ }^{*}$ Results are significantly different between the control (Ctrl, $\left.n 21\right)$ and iron-deficient (Fe Def, $n$ 24) groups $(P<0.05$; Mann-Whitney test). ATOX1, antioxidant 1 copper chaperone; COX17, cytochrome $c$ oxidase chaperone; ATP7A, ATPase copper transporting alpha (Menkes); ATP7B, ATPase copper transporting beta (Wilson); CCS, copper chaperone for superoxide dismutase; CP, ceruloplasmin; CTR1, copper transporter 1. 

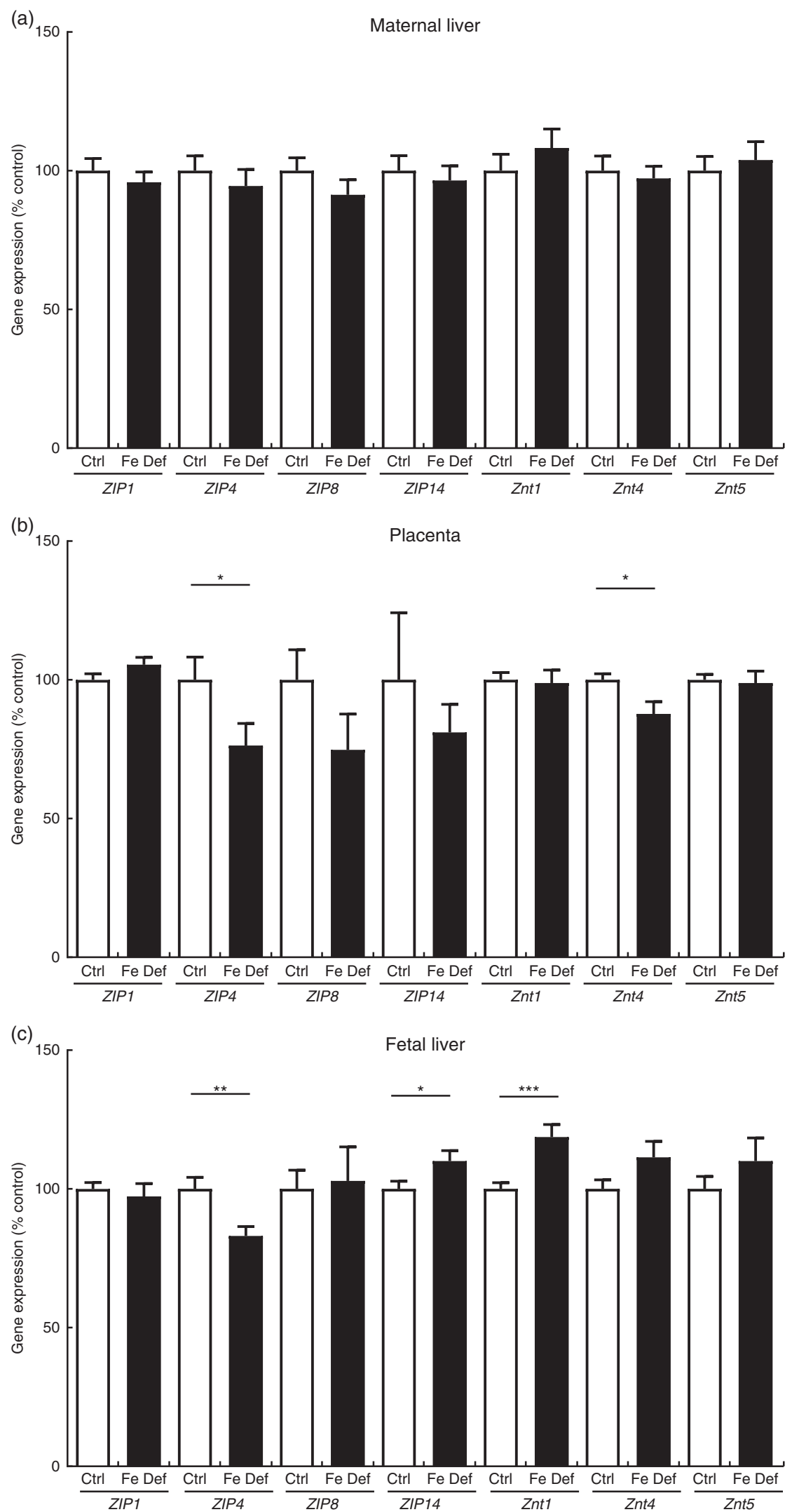

Fig. 3. Effect of maternal iron deficiency on the expression of genes related to zinc metabolism ( $n 45) 21 \mathrm{~d}$ after mating: (a) maternal liver; (b) placenta; (c) fetal liver. Values are mean percentage of control, with their standard errors represented by vertical bars. Results are significantly different between the control (Ctrl, $n 21)$ and iron-deficient (Fe Def, $n$ 24) groups: ${ }^{*} P<0.05,{ }^{* *} P<0.01,{ }^{* * *} P<0.001$ (Mann-Whitney test). ZIP1, ZRT/IRT-like protein 1; ZIP4, ZRT/IRT-like protein 4; ZIP8, ZRT/ IRT-like protein; ZIP14, ZRT/IRT-like protein 14; ZnT1, zinc transporter 1; ZnT4, zinc transporter 4; ZnT5, zinc transporter 5. 
Table 3. Summary of the effect of maternal iron deficiency on copper and zinc metabolism in maternal liver, placenta and fetal liver at day 21 of pregnancy*

\begin{tabular}{|c|c|c|c|}
\hline Gene & Maternal liver & Placenta & Fetal liver \\
\hline Cu† & $\uparrow \uparrow$ & $\uparrow$ & $\downarrow$ \\
\hline ATOX1‡ & $\downarrow$ & $=$ & $=$ \\
\hline $\operatorname{cox} 17 \neq$ & $\downarrow$ & $=$ & $\uparrow$ \\
\hline CCS $\ddagger$ & $=$ & $\downarrow$ & $=$ \\
\hline$C P \ddagger$ & $=$ & $\downarrow$ & $=$ \\
\hline ATP7A & $=$ & $=$ & $=$ \\
\hline ATP7B $\ddagger$ & $=$ & $=$ & $=$ \\
\hline CTR1‡ & $=$ & $=$ & $=$ \\
\hline$Z n \dagger$ & $=$ & $=$ & $\uparrow \uparrow$ \\
\hline ZIP1‡ & $=$ & $=$ & $=$ \\
\hline ZIP4‡ & $=$ & $\downarrow$ & $\downarrow$ \\
\hline ZIP8 & $=$ & $=$ & $=$ \\
\hline ZIP14‡ & $=$ & $=$ & $\uparrow$ \\
\hline ZnT1 & $=$ & $=$ & $\uparrow$ \\
\hline ZnT4‡ & $=$ & $\downarrow$ & $=$ \\
\hline ZnT5‡ & $=$ & $=$ & $=$ \\
\hline
\end{tabular}

ATOX1, antioxidant $1 \mathrm{Cu}$ chaperone; COX17, cytochrome $c$ oxidase $\mathrm{Cu}$ chaperone; CCS, Cu chaperone for superoxide dismutase; CP, ceruloplasmin; ATP7A, ATPase $\mathrm{Cu}$ transporting alpha (Menkes); ATP7B, ATPase Cu transporting beta (Wilson); CTR1, Cu transporter 1; ZIP, ZRT/IRT-like protein; ZnT, Zn transporter.

* The concentrations of $\mathrm{Cu}, \mathrm{Zn}$, and the expression of genes of $\mathrm{Cu}$ and $\mathrm{Zn}$ metabolism were either greatly increased $(\uparrow \uparrow)$, increased $(\uparrow)$, decreased $(\downarrow)$ or unchanged $(=)$ by maternal Fe deficiency.

$\dagger n 54$ (control $n$ 24, Fe deficient $n$ 30).

$\ddagger n 45$ (control $n 21$, Fe deficient $n$ 24).

although whether this is cause or consequence is not certain at this time. There are little data on the direct effects of $\mathrm{Cu}$ on either $A T O X 1$ or $C O X 17$ expression, so the possibility that these changes are a response to changes in $\mathrm{Cu}$ levels, rather than $\mathrm{Cu}$ levels being changed by the alterations in gene expression, cannot be excluded in these experiments.

As observed previously ${ }^{(23)}$, maternal Fe deficiency led to the increase in $\mathrm{Cu}$ levels in the placenta (approximately 19\%) to a greater extent than the maternal liver (approximately 10\%). This was accompanied by the reduction in CCS expression, another chaperone channeling $\mathrm{Cu}$ for incorporation into the $\mathrm{Cu}-\mathrm{Zn}$ superoxide dismutase (SOD) complex, an essential component of the anti-oxidant cell system. $\mathrm{Cu}$ has been shown to modulate the degradation of $C C S^{(43)}$ and $\mathrm{Cu}$ supplementation in humans reduces CCS mRNA levels in peripheral mononuclear cells ${ }^{(44)}$. It is likely that the down-regulation of CCS expression observed here is due to the presence of elevated $\mathrm{Cu}$ levels in the placenta, rather than a direct consequence of reduced Fe levels. Our findings suggest that maternal Fe deficiency leads to the impairment of SOD activity (closely related to CCS expression) and the anti-oxidant defense of the placenta as observed in liver and brain cells upon $\mathrm{Cu}$ accumulation ${ }^{(45,46)}$.

$\mathrm{CP}$ is involved in $\mathrm{Fe}$ export in the liver, oxidising $\mathrm{Fe}(\mathrm{II})$ to $\mathrm{Fe}$ (III) for incorporation into transferrin, while its homologue zyklopen performs the same function in placenta in mice and humans ${ }^{(47)}$. Whether the ferroxidase mRNA measured in the placenta is zyklopen, $\mathrm{CP}$ or a combination of both remains uncertain, since the sequences are very similar and because the primers are from a commercial supplier. However, it is likely that we measured the mRNA coding for a multi-copper oxidase responsible for Fe export ${ }^{(48)}$. The effect that the reduced placental expression might have on Fe transport is not clear and contrasts with previous findings ${ }^{(48)}$. However, it is important to note that $\mathrm{CP}$ protein and enzyme levels do not correlate with mRNA levels ${ }^{(49)}$ and that changes in $C P$ mRNA expression observed in the present study may therefore have little physiological impact. Maternal Fe deficiency is partly alleviated in the fetus, due to increased expression of transferrin receptors ${ }^{(50,51)}$, which would imply that ferroxidase expression or activity is not rate limiting.

$\mathrm{Cu}$ transport across the placenta is less well-understood. $\mathrm{Cu}$ appears to be taken up from the maternal circulation through CTR 1 and excreted through ATPases ${ }^{(52,53)}$. It has been suggested that $A T P 7 A$ is responsible for the efflux of $\mathrm{Cu}$ from the basolateral membrane into the fetal circulation, while $A T P 7 B$ is responsible for excreting $\mathrm{Cu}$ back into the maternal circulation at the apical side $^{(54)}$. Whether $\mathrm{CP}$ and/or zyklopen are involved in $\mathrm{Cu}$ efflux and/or delivery to the fetal liver, as we have previously ${ }^{(54)}$ suggested for transport of $\mathrm{Cu}$ from the mother to the placenta ${ }^{(55)}$, and whether this could explain the differences observed in $\mathrm{Cu}$ levels between placenta and fetal liver remain to be clarified.

\section{Effects of maternal iron deficiency on zinc metabolism}

The effect of Fe deficiency on $\mathrm{Zn}$ metabolism in the pregnant rat is less marked than for $\mathrm{Cu}$ but is nonetheless significant. $\mathrm{Zn}$ levels in the maternal liver and placenta were not changed but were markedly increased in the fetal liver.

In the maternal liver, the expression of the genes of $\mathrm{Zn}$ metabolism tested were unchanged, which is consistent with the lack of effect on $\mathrm{Zn}$ levels but contrasts with previous findings in male rats, where Fe deficiency led to an increase in hepatic ZIP14 expression ${ }^{(19)}$. It should be noted, however, that the authors also observed a small decrease in $\mathrm{Zn}$ levels which was not seen in the present study nor in their other study of a similar design ${ }^{(19)}$. Taken together, these results imply that $\mathrm{Fe}$ deficiency during pregnancy is unlikely to lead to changes in $\mathrm{Zn}$ metabolism that are physiologically important in the maternal liver.

While $\mathrm{Zn}$ levels were unchanged in the placenta, ZIP4 and $Z n T 4$, genes of $Z n$ cellular uptake and exit, respectively, were both decreased in the placenta. The results do not fully match those seen in mice given a Zn-deficient diet, where ZnT4 and also $Z I P 1, Z n T 1$ and 5 were reduced in placenta ${ }^{(33)}$. It is possible that there was a mild reduction in $\mathrm{Zn}$ supply to and in efflux from the placenta, with a neutral net effect on $Z n$ levels in the placenta. Zn metabolism and transport in the placenta are still not entirely understood, and the role and localisation of ZIP4 in the placenta are not known. ZIP4 is crucial for $\mathrm{Zn}$ cellular uptake in the small intestine and is up-regulated upon $\mathrm{Zn}$ deficiency in mice ${ }^{(56)}$. It is also abundantly expressed in other tissues involved in nutrient absorption and reabsorption (stomach, colon and kidney) ${ }^{(57)}$. While ZIP4 expression could not be compared with intestinal or kidney expression in the present study, it is important to note that it was higher in the placenta compared with maternal liver (approximately 2-fold) and fetal liver (approximately 15-fold, data not shown). This suggests that the changes observed in placental expression could be biologically relevant, and further research is warranted to clarify the role of ZIP4 in placenta. If it was involved in the 
return of $\mathrm{Zn}$ from fetal to maternal circulation, then decreased expression could result in increased levels of $\mathrm{Zn}$ in the fetal liver. Interestingly, neither ZIP\& nor ZIP14, both of which have previously been implicated in Fe metabolism as well as that of $\mathrm{Zn}^{(32)}$, are altered in the placenta or maternal liver, which would argue against the changes in fetal liver $\mathrm{Zn}$ levels being a direct consequence of competition with Fe for these transporters.

Fe deficiency leads to an increase in $\mathrm{Zn}$ levels in the fetal liver but also a lesser decrease in Fe levels compared with the decrease observed in the maternal liver ${ }^{(58)}$. Both these changes may be explained, at least partially, by an upregulation of ZIP14, which mediates the uptake of $\mathrm{Zn}$, as well as nontransferrin-bound $\mathrm{Fe}^{(31)}$, and thus could help protect the fetus against Fe deficiency. It is important to note that this does not rule out other mechanisms, such as an increased expression of transferrin receptors, as we have previously observed in the placenta of rats and women ${ }^{(50,51)}$. On the other hand, the reduced ZIP4 expression in the fetal liver is more likely to be a consequence of the increase in $\mathrm{Zn}$ levels as has been seen in $\mathrm{Zn}$ overload observed in the intestine and visceral yolk sac of mice ${ }^{(56)}$. In addition, as described earlier in this discussion, ZIP4 expression in the fetal liver was fairly low compared with the other tissues, indicating that its changes may have little biological relevance.

Contrasting with our results, $Z n T 1$ hepatic upregulation has been reported in $\mathrm{Zn}$-deficient rats in association with $\mathrm{Zn}$ depletion in the liver ${ }^{(59)}$, although this was only observed at the protein level. Whether the increase in ZnT1 mRNA expression in the fetal liver would lead to an increase in protein levels is uncertain, and whether this could lead to more Zn efflux back into the fetal circulation is unlikely in the present study. The reasons why $Z n T 1$ upregulation is associated with a marked increase in $Z n$ levels are not known, and the role of $Z n T 1$ in fetal liver $\mathrm{Zn}$ metabolism needs to be clarified.

In summary, this study has shown that Fe deficiency has opposite effects on $\mathrm{Cu}$ and $\mathrm{Zn}$ levels in the fetal liver, and this is associated with changes in the expression of genes of $\mathrm{Cu}$ and $\mathrm{Zn}$ metabolism in the placenta as well as in the fetus. It is important to note that some of these effects may not be directly caused by Fe deficiency but rather by changes in the metabolism of the other two nutrients. The results further demonstrate that micronutrient metabolism, especially during pregnancy, is tightly interlinked and underscores the importance of considering all of the micronutrients when trying to alleviate deficiencies in one of them. It would be important to consider that the symptoms caused by deficiencies in one micronutrient (here Fe) may not be caused directly by that deficiency but by other deficiencies or overloads occurring as a consequence of the primary defect.

\section{Acknowledgements}

The authors are grateful for the technical assistance of Gill Campbell (ICP-MS analysis).

This work was supported and funded by Scottish Government (Rural and Environment Science and Analytical Services).

H. J. M., L. G. and S. C. C. designed the research; L. G., H. E. H., V. J. C. and S. C. C. conducted the research; S. C. C. analysed the data and wrote the manuscript; G. R. and H. J. M. reviewed the manuscript. H. J. M., G. R. and S. C. C. take responsibility of data interpretation and presentation. All authors read and approved the final manuscript.

The authors declare that there are no conflicts of interest.

\section{References}

1. Miller R, Spiro A \& Stanner S (2016) Micronutrient status and intake in the UK - where might we be in 10 years' time? Nutr Bull 41, 14-41.

2. Collins JF, Prohaska JR \& Knutson MD (2010) Metabolic crossroads of iron and copper. Nutr Rev 68, 133-147.

3. Gambling L, Kennedy C \& McArdle HJ (2011) Iron and copper in fetal development. Semin Cell Dev Biol 22, 637-644.

4. Whittaker P (1998) Iron and zinc interactions in humans. AmJ Clin Nutr 68, 446S.

5. Owen CA Jr (1973) Effects of iron on copper metabolism and copper on iron metabolism in rats. Am J Physiol 224, 514-518.

6. Ravia JJ, Stephen RM, Ghishan FK, et al. (2005) Menkes copper ATPase (ATP7A) is a novel metal-responsive gene in rat duodenum and immunoreactive protein is present on brush border and basolateral membrane domains. J Biol Chem 280, 36221-36227.

7. Sourkes TL, Lloyd K \& Birnbaum H (1968) Inverse relationship of heptic copper and iron concentrations in rats fed deficient diets. Can J Biochem 46, 267-271.

8. Ranganathan PN, Lu Y, Jiang L, et al. (2011) Serum ceruloplasmin protein expression and activity increases in irondeficient rats and is further enhanced by higher dietary copper intake. Blood 118, 3146-3153.

9. Collins JF, Franck CA, Kowdley KV, et al. (2005) Identification of differentially expressed genes in response to dietary iron deprivation in rat duodenum. Am J Physiol 288, G971.

10. Jiang L, Garrick MD, Garrick LM, et al. (2013) Divalent metal transporter 1 (Dmt1) mediates copper transport in the duodenum of iron-deficient rats and when overexpressed in irondeprived HEK-293 cells. J Nutr 143, 1927-1933.

11. Shukla A, Agarwal KN \& Shukla GS (1990) Effect of latent iron deficiency on the levels of iron, calcium, zinc, copper, manganese, cadmium and lead in liver, kidney and spleen of growing rats. Experientia 46, 751-752.

12. Shukla A, Agarwal KN \& Shukla GS (1989) Effect of latent iron deficiency on metal levels of rat brain regions. Biol Trace Elem Res 22, 141-152.

13. Kaganda J, Matsuo T \& Suzuki H (2003) Development of iron deficiency decreases zinc requirement of rats. J Nutr Sci Vitaminol (Tokyo) 49, 234-240.

14. Yokoi K, Kimura M \& Itokawa Y (1991) Effect of dietary iron deficiency on mineral levels in tissues of rats. Biol Trace Elem Res 29, 257-265.

15. Stangl GI \& Kirchgessner M (1998) Effect of different degrees of moderate iron deficiency on the activities of tricarboxylic acid cycle enzymes, and the cytochrome oxidase, and the iron, copper, and zinc concentrations in rat tissues. $Z$ Ernahrungswiss 37, 260-268.

16. Tallkvist J, Bowlus CL \& Lonnerdal B (2000) Functional and molecular responses of human intestinal Caco-2 cells to iron treatment. Am J Clin Nutr 72, 770-775.

17. Illing AC, Shawki A, Cunningham CL, et al. (2012) Substrate profile and metal-ion selectivity of human divalent metal-ion transporter-1. J Biol Chem 287, 30485-30496.

18. Guerinot ML (2000) The ZIP family of metal transporters. Biochim Biophys Acta 1465, 190-198.

19. Nam H \& Knutson MD (2012) Effect of dietary iron deficiency and overload on the expression of ZIP metal-ion transporters in rat liver. Biometals 25, 115-124. 
20. Sherman AR \& Moran PE (1984) Copper metabolism in irondeficient maternal and neonatal rats. J Nutr 114, 298-306.

21. Sherman AR \& Tissue NT (1981) Tissue iron, copper and zinc levels in offspring of iron-sufficient and iron-deficient rats. J Nutr 111, 266-275.

22. Gambling L, Dunford S \& McArdle HJ (2004) Iron deficiency in the pregnant rat has differential effects on maternal and fetal copper levels. J Nutr Biochem 15, 366-372.

23. Gambling L, Andersen HS, Czopek A, et al. (2004) Effect of timing of iron supplementation on maternal and neonatal growth and iron status of iron-deficient pregnant rats. J Physiol 561, 195-203.

24. Lenartowicz M, Kennedy C, Hayes H, et al. (2015) Transcriptional regulation of copper metabolism genes in the liver of fetal and neonatal control and iron-deficient rats. Biometals 28, 51-59.

25. Fung EB, Ritchie LD, Woodhouse LR, et al. (1997) Zinc absorption in women during pregnancy and lactation: a longitudinal study. Am J Clin Nutr 66, 80-88.

26. Hambidge KM, Krebs NF, Jacobs MA, et al. (1983) Zinc nutritional status during pregnancy: a longitudinal study. $A m \mathrm{~J}$ Clin Nutr 37, 429-442.

27. Fischer-Walker CF, Kordas K, Stoltzfus RJ, et al. (2005) Interactive effects of iron and zinc on biochemical and functional outcomes in supplementation trials. Am J Clin Nutr 82, 5-12.

28. Cottin SC, Gambling L, Hayes HE, et al. (2016) Pregnancy and maternal iron deficiency stimulate hepatic CRBPII expression in rats. J Nutr Biochem 32, 55-63.

29. Segawa S, Shibamoto M, Ogawa M, et al. (2014) The effect of divalent metal cations on zinc uptake by mouse Zrt/Irt-like protein 1 (ZIP1). Life Sci 113, 40-44.

30. Andrews GK (2008) Regulation and function of Zip4, the acrodermatitis enteropathica gene. Biochem Soc Trans 36, 1242-1246.

31. Liuzzi JP, Aydemir F, Nam H, et al. (2006) Zip14 (Slc39a14) mediates non-transferrin-bound iron uptake into cells. Proc Natl Acad Sci U S A 103, 13612-13617.

32. Wang CY, Jenkitkasemwong S, Duarte S, et al. (2012) ZIP8 is an iron and zinc transporter whose cell-surface expression is up-regulated by cellular iron loading. I Biol Chem 287, 34032-34043

33. Helston RM, Phillips SR, McKay JA, et al. (2007) Zinc transporters in the mouse placenta show a coordinated regulatory response to changes in dietary zinc intake. Placenta $\mathbf{2 8}$ 437-444.

34. Liuzzi JP, Bobo JA, Cui L, et al. (2003) Zinc transporters 1, 2 and 4 are differentially expressed and localized in rats during pregnancy and lactation. J Nutr 133, 342-351.

35. Bustin SA, Benes V, Garson JA, et al. (2009) The MIQE guidelines: minimum information for publication of quantitative real-time PCR experiments. Clin Chem 55, 611-622.

36. Kambe T, Weaver BP \& Andrews GK (2008) The genetics of essential metal homeostasis during development. Genesis $\mathbf{4 6}$, 214-228.

37. Hardman B, Michalczyk A, Greenough M, et al. (2007) Distinct functional roles for the Menkes and Wilson copper translocating P-type ATPases in human placental cells. Cell Physiol Biochem 20, 1073-1084.

38. Hamza I, Faisst A, Prohaska J, et al. (2001) The metallochaperone Atox1 plays a critical role in perinatal copper homeostasis. Proc Natl Acad Sci U S A 98, 6848-6852.

39. Hamza I, Prohaska J \& Gitlin JD (2003) Essential role for Atox1 in the copper-mediated intracellular trafficking of the Menkes ATPase. Proc Natl Acad Sci U S A 100, 1215-1220.

40. Safaei R, Maktabi MH, Blair BG, et al. (2009) Effects of the loss of Atox1 on the cellular pharmacology of cisplatin. J Inorg Biochem 103, 333-341.
41. Masini A, Salvioli G, Cremonesi P, et al. (1994) Dietary iron deficiency in the rat. I. Abnormalities in energy metabolism of the hepatic tissue. Biochim Biophys Acta 1188, 46-52.

42. Walter PB, Knutson MD, Paler-Martinez A, et al. (2002) Iron deficiency and iron excess damage mitochondria and mitochondrial DNA in rats. Proc Natl Acad Sci U S A 99, 2264-2269.

43. Bertinato J \& L'Abbé MR (2003) Copper modulates the degradation of copper chaperone for $\mathrm{Cu}, \mathrm{Zn}$ superoxide dismutase by the $26 \mathrm{~S}$ proteosome. J Biol Chem 278, 35071-35078.

44. Araya M, Andrews M, Pizarro F, et al. (2012) Chaperones CCS, ATOX and COXIV responses to copper supplementation in healthy adults. Biometals 25, 383-391.

45. Ozcelik D \& Uzun H (2009) Copper intoxication; antioxidant defenses and oxidative damage in rat brain. Biol Trace Elem Res 127, 45-52.

46. Zhang SS, Noordin MM, Rahman SO, et al. (2000) Effects of copper overload on hepatic lipid peroxidation and antioxidant defense in rats. Vet Hum Toxicol 42, 261-264.

47. Chen H, Attieh ZK, Syed BA, et al. (2010) Identification of zyklopen, a new member of the vertebrate multicopper ferroxidase family, and characterization in rodents and human cells. J Nutr 140, 1728-1735.

48. Danzeisen R, Fosset C, Chariana Z, et al. (2002) Placental ceruloplasmin homolog is regulated by iron and copper and is implicated in iron metabolism. Am J Physiol 282, C478-C483.

49. McArdle HJ, Mercer JF, Sargeson AM, et al. (1990) Effects of cellular copper content on copper uptake and metallothionein and ceruloplasmin mRNA levels in mouse hepatocytes. J Nutr 120, 1370-1375.

50. Cornock R, Gambling L, Langley-Evans S, et al. (2013) The effect of feeding a low iron diet prior to and during gestation on fetal and maternal iron homeostasis in two strains of rat. Reprod Biol Endocrinol 11, 32.

51. Garcia-Valdes L, Campoy C, Hayes H, et al. (2015) The impact of maternal obesity on iron status, placental transferrin receptor expression and hepcidin expression in human pregnancy. Int J Obes (Lond) 39, 571-578.

52. Kuo Y, Zhou B, Cosco D, et al. (2001) The copper transporter CTR1 provides an essential function in mammalian embryonic development. Proc Natl Acad Sci U S A 98, 6836-6841.

53. McArdle HJ, Andersen HS, Jones H, et al. (2008) Copper and iron transport across the placenta: regulation and interactions. J Neuroendocrinol 20, 427-431.

54. Hardman B, Manuelpillai U, Wallace EM, et al. (2004) Expression and localization of Menkes and Wilson copper transporting ATPases in human placenta. Placenta 25, 512-517.

55. Hilton M, Spenser DC, Ross P, et al. (1995) Characterisation of the copper uptake mechanism and isolation of the ceruloplasmin receptor/copper transporter in human placental vesicles. Biochim Biophys Acta 1245, 153-160.

56. Dufner-Beattie J, Wang F, Kuo YM, et al. (2003) The acrodermatitis enteropathica gene ZIP4 encodes a tissue-specific, zinc-regulated zinc transporter in mice. $J$ Biol Chem $\mathbf{2 7 8}$, 33474-33481.

57. Wang K, Zhou B, Kuo YM, et al. (2002) A novel member of a zinc transporter family is defective in acrodermatitis enteropathica. Am J Hum Genet 71, 66-73.

58. Gambling L, Charania Z, Hannah L, et al. (2002) Effect of iron deficiency on placental cytokine expression and fetal growth in the pregnant rat. Biol Reprod 66, 516-523.

59. Jou MY, Hall AG, Philipps AF, et al. (2009) Tissue-specific alterations in zinc transporter expression in intestine and liver reflect a threshold for homeostatic compensation during dietary zinc deficiency in weanling rats. J Nutr 139, 835-841. 